\title{
REFLECTION
}

\section{Parenting My Transgender Child: From Loss to Acceptance}

\author{
Justine Larson, MD, MPH \\ Sheppard Pratt, Baltimore, Maryland
}

Conflicts of interest: author is consulting editor for the Child and Adolescent Psychiatric Clinics of North America but otherwise bas no disclosures or conflicts of interest.

\section{CORRESPONDING AUTHOR}

Justine Larson

Sheppard Pratt

515 Philadelphia Ave

Takoma Park, MD 20912

justine.larson1@sheppardpratt.org

\begin{abstract}
At age 11, my child Neo told me he was a boy and not a girl, as assigned at birth. Despite my training as a child and adolescent psychiatrist, I struggled to accept his declaration and had to learn how to best support him. He was never a typical girl, but when he decided he was transgender, my husband and I navigated the adjustment to new pronouns, a name change, the transition at school, and telling friends and family. Seeing Neo's sadness and despondency when he was not accepted sparked me to educate myself about medical options for transgender individuals and other ways to be gender affirming. Although I initially felt a sense of loss and hurt about Neo being transgender, these feelings changed to acceptance and pride as I watched Neo change and grow. Neo taught me to challenge societal dichotomies and taught me about how physicians in particular can support families with gender-creative children.
\end{abstract}

Ann Fam Med 2021;19:556-559. https://doi.org/10.1370/afm.2737.

W hen my husband and I were expecting our first child, we chose a name honoring my grandmother Evelyn, a family leader and a comfort to her children. At age 11, our child told us he was a boy and not, as assigned at birth, a girl. Later, he chose the name Neo.

I'm here to tell you about my experiences-not as a physician and child psychiatrist, but as a parent-with having a transgender child. Being a child and adolescent psychiatrist doesn't always give me the answers to being a parent. Many of the fancy things we learn completely go out the window when it comes to our own children. Having these experiences as a parent, however, has given me insights into what physicians can do to support families of gender-creative youth. Of note, "he and his" pronouns are used throughout this article when referring to $\mathrm{Neo}$, as requested by $\mathrm{Neo}$ himself, who says, "I was a boy even before you realized it, Mama."

In preschool, at age 2, Neo's teachers began to pull us aside saying he was not sitting like the other children for circle time. We moved him to a school based on the Waldorf education model, where he could run outside and jump off logs. His teachers, who all wore long flowing skirts, told us that he tended to play with the older boys. Once, when he was 4, he told me that all the girls liked to play was "Maiden," which was a Waldorfschool version of "house."

He said to me, "Mama, I don't like to play Maiden. But sometimes I pretend to like to play Maiden, so I can have someone to play with."

He was a tiny child, with long, blond hair that was often unkemptalways getting snarled and knotted. Despite being small and having long hair, he was often mistaken for a boy. When describing him, I sometimes told people that he had a "boy energy." Preemptively, I found myself using the "she" pronoun before people had a chance to try to figure it out. I also corrected people if they referred to him as "he." Once, Neo told me, "I don't like it when you correct people when they say 'he.' It's fine with me." 
He was never a typical "girl" — playing very rough, not being particularly interested in things that are "girly." But this did not seem that strange to me. I was proud that he felt he could be a non-typical girl, maybe giving myself credit for not overly enforcing gender norms.

\section{HE WAS READY. WE WERE NOT}

When he was 11, it seemed like things shifted for him. One evening, our family was sitting in a bookstore café, in the corner of the restaurant. Neo seemed to be a little bit agitated and upset. Finally, he told my husband and I that he had something to tell us.

"I'm a boy," he said.

My husband and I said something like, "You don't have to decide right now."

"No," he said, "I've already decided."

He was ready. We were not.

\section{ANXIOUS AND CONFUSED}

To be honest, I did not want him to be transgender. I was afraid it would be a hard life, a life of facing discrimination and people feeling weird around him. I was afraid of the medical interventions. With my limited knowledge, there was almost a quality of self-mutilation about some of the interventions. Removing one's breasts, blocking a hormone, injecting other hormones, or removing part of your arm to make a penis. When I thought about these interventions for my child—it felt violent and frightening. I felt sad for him that he didn't feel right in his body.

I also felt a sense of hurt. I felt like he was rejecting the body that his dad and I had given him. I felt hurt that he was rejecting femaleness. Did I not teach him enough about the fact that you can be any kind of girl or woman that you want to be? You can wear what you want, love whom you want? Did he think somehow boys were better than girls, that it was better to be a boy than a girl?

I was completely unsure of how to respond. With my training in child and adolescent psychiatry, I understood the concept of being "gender affirming." I was anxious and confused about how "gender affirming" to be, how radical to be in accepting his declaration. My husband was concerned about whether we were "encouraging" him to be transgender. He wondered whether Neo was naïve about the fact that it was a harder life, and wanted to be a boy because, maybe it seemed like more fun. Was Neo entering into a harder life without fully understanding the implications of a decision like changing your gender?

After his declaration in the café, the issue went dormant for a few weeks. I'm not proud of it now. Neo has told me that he was hurt that we did not act more forcefully after he told us he was a boy. It had taken a lot of courage to tell us. Our not responding made him feel more alone.

Over the next several weeks, Neo seemed increasingly down. For Halloween, he made an elaborate toilet costume. His friends dressed as poop emojis. I looked at him as they were getting ready for trick-o-treating. He looked exhausted and miserable. It was almost like he felt like a toilet.

My husband and I were having intense discussions, even arguments. We felt incredibly conflicted. On the one hand, I wanted to embrace Neo's trans status by attending youth pride events, by beginning to call him "he," and strategizing with him on coming out to others. On the other hand, we continued to be unsure.

\section{I'LL ALWAYS BE A BOY}

Amid these ruminations, in early November, Neo and I went out for sushi. He had his hoodie up, and looked dejected, staring at his California rolls. I demanded he take his hoodie down and help me understand.

"Mama," he said to me, "if I get my period, that will be the end for me. I don't want to kill myself, but I feel like I wouldn't want to live anymore if I got my period."

We packaged the California rolls to go. In a flurry, we acquired a trans flag to hang on our porch, all kinds of books about gender fluidity, hormones, and parenting. We joined several groups for transgender kids. We set up evaluations at several gender clinics.

After that, everything came fast. Telling grandparents, telling the school, coming out to friends, pronouns, and hormones.

The name was hard for us. I remember sitting on Neo's bed one night when Neo asked me, "Will Grandma Evelyn be upset?"

"Grandma Evelyn would understand," I said.

Neo developed a long list of possible names and we discussed them. Eventually, he chose the name Neo because it meant "New" and "Enlightened."

He stood in front of his 6th grade class with a letter: "I have felt like I was a boy since I was little," the letter said, "and it's been bothering me for a while. From now on, I want to go by $\mathrm{Neo}$ and I would like for people to call me 'he."'

Afterwards, Neo said a few of the boys came up to him and said, "Congratulations, bro." Another girl told him he was brave. Another boy said, "Your haircut still sucks." And, essentially, with the other kids, that was that.

I won't lie. I cried that day. I felt loss-loss about my idea of this girl named Evelyn. Everyone else, 
seemingly, was more excited about Neo being trans than I was.

"How wonderful that he can be his authentic, true self!" people said. True-but there was loss and confusion too. People were eager to be gender affirming, for which I am grateful. But I wondered-were we celebrating too much?

Regarding medical treatments, I learned that many youths benefit from hormone blockers, and we agreed with trepidations to his starting them. Six months later, however, Neo flipped it on us:

"I don't want to get the shot anymore," he said.

He told the pediatrician that he was comfortable being a male with some female characteristics: "I feel like I have the resources now. I'm comfortable enough with my gender and I don't feel like I have to look totally like a boy."

I have learned since then that many gender-creative people choose different ways to physically express their gender - some choose not to take hormones or get surgeries, while others do benefit from them. It may be easy to mistake this comfort with different expressions as ambivalence with one's gender identity. When I asked him about this, Neo rolled his eyes, "I'll always be a boy, mama," he said.

Gender-creative youth need their families to give them permission to be who they are. It is understandable, though, for families to struggle with this; they need nonjudgmental support and time to adjust. Neo is part of an educated, liberal family and it was hard for us. It takes time. Even in the best of circumstances, children are under intense pressure to conform to their assigned sex. My own experience highlighted that some behaviors from family members that appear to be rejecting may be motivated by concern and love for the child.

\section{SUPPORTING YOUTH AND FAMILIES}

Having a transgender child has taught me about the important role that physicians can play in compassionately supporting the families who are struggling to embrace their gender-creative child. As physicians, we need to understand how important a parent's approval is to any youth. With the increased rates of suicidal ideation and homelessness among LBGTQ+ youth, ${ }^{1,2}$ related in part to family rejection, ${ }^{3}$ it is absolutely the domain of physicians to help families support and accept their gender-diverse child. Physicians can discuss the importance of acceptance with parents and guardians and provide education to family members and guardians about what being transgender or non-binary is. Highlighting how much the parent or guardian's love and opinion means to the child can be helpful. The Family Acceptance Project has extensive resources available to inform clinicians working with families of LBGTQ+ youth ${ }^{4,5}$ (eg, Family Acceptance Project $\left.{ }^{5}\right)$. Acknowledging this love and caring intention that parents and caregivers have for their children, while also informing families about the impacts of not fully accepting their child, can be an important role for the physician.

\section{REFLECTIONS}

Now, Neo is a happy kid. He loves chickens, camping, and is fascinated by the Arctic. He has sleepovers with his friends in his treehouse. He babysits several kids in the neighborhood and made a vegetable garden in the front yard. He dreams of traveling to Malta, Norway, and Greenland. He cares about global warming and the Black Lives Matter movement. Being trans is not something he's too focused on right now, although he still attends sleepaway camp for gender-creative kids. "It isn't a big part of my life right now," he says, shrugging. Our problems are the problems of many families-getting him to be kinder to his brother, to pay attention more in math class, and not leave dirty cereal bowls in the TV room.

Neo can say clearly who he is and what he wants, something I still struggle to do, in the face of intense societal pressure to conform to specific gender roles. How cool is it that he doesn't accept the world as he's told it "is"? What other things will he look at in the world and challenge to be something else?

Am I scared for him? You bet. When you think about it, there's a lot for parents to be scared of: from global issues like climate change, economic recessions, ongoing effects of the pandemic; to national issues like mass shootings in schools, the rise in white supremacy, and recent political initiatives to reduce the rights of trans youth; to highly personal issues like getting him through college with his ADHD, teaching him to be a considerate friend and husband one day, the list goes on. But what better way to equip him for the future than to let him know he is loved, that I'm proud of him, and that he should trust his feelings and his voice?

For myself, seeing Neo challenge his assigned gender role has made me think about my own perceptions of gender with my patients and in my personal interactions. I am aware that in some ways our family is an exception-I'm a child and adolescent psychiatrist, living in an LBGTQ+-friendly community, we have resources, and an accepting extended family. Despite these advantages, our experience can inform other common experiences for families - the sense of loss and fear, the confusion about which experts to listen to, the desire for parents to "protect" their child 
paradoxically making the child feel rejected and alone. Neo has also made me think more broadly about other societal dichotomies, such as our polarized political climate. Just as there are many ways to be a man, a woman, or a human, perhaps there are more choices of who to be other than "us" or "them."

To read or post commentaries in response to this article, go to https://www. AnnFamMed.org/content/19/6/556/tab-e-letters.

Key words: transgender persons; gender identity

Submitted January 19, 2021; submitted, revised, April 27, 2021; accepted May 10, 2021.

Acknowledgments: I would like to thank Neo for his willingness and openness for me to publish this article. Neo understands that the article will be in the public space, and would like to be helpful to other gender-creative youth and their families.

\section{References}

1. Eisenberg ME, Kelly ED, McRee AL, Brady SS, Barnes AJ. Homelessness experiences and gender identity in a population-based sample of adolescents. Prev Med Rep. 2019;16:100986.

2. Thoma BC, Salk RH, Choukas-Bradley S, Goldstein TR, Levine MD, Marshal MP. Suicidality disparities between transgender and cisgender adolescents. Pediatrics. 2019;144(5):e20191183. 10.1542/ peds.2019-1183

3. Tankersley AP, Grafsky EL, Dike J, Jones RT. Risk and resilience factors for mental health among transgender and gender nonconforming (TGNC) youth: a systematic review. Clin Child Fam Psychol Rev. 2021;24(2):183-206. 10.1007/s10567-021-00344-6

4. Substance Abuse and Mental Health Services Administration. A Practitioner's Resource Guide: Helping Families to Support Their LGBT Children. HHS Publication No. PEP14-LGBTKIDS. Substance Abuse and Mental Health Services Administration; 2014.

5. Family Acceptance Project. Accessed Apr 1, 2021. https://familyproject.sfsu.edul

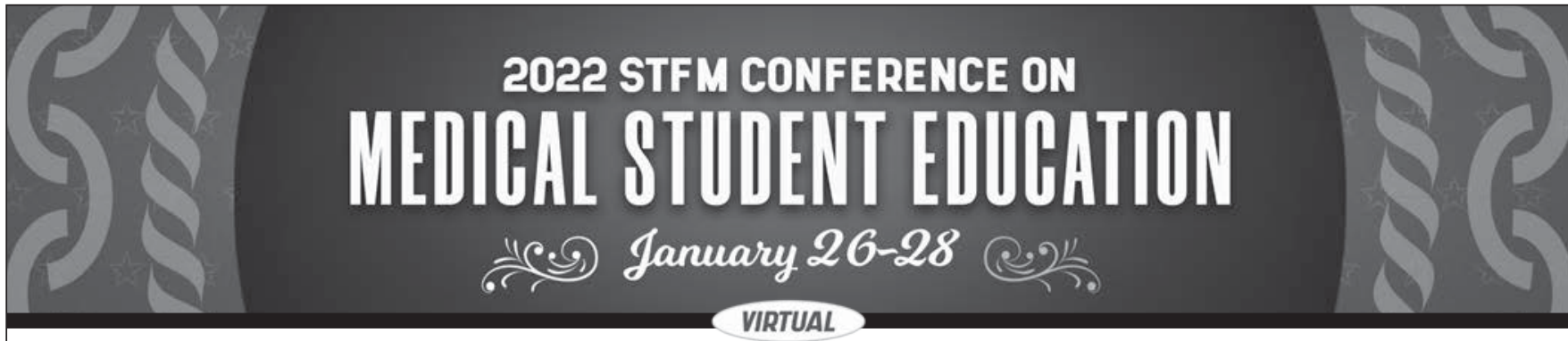

NOTE: The 2022 STFM Conference on Medical Student Education originally scheduled for January 27-30, 2022 in San Antonio, Texas has been replaced with a virtual conference scheduled for January 26-28, 2022 (Wednesday through Friday).

\section{Join Family Medicine Colleagues Virtually}

COLLABORATE and ENERGIZE with those with an interest in family medicine education INWOVATE and EMPOWER students, faculty, coordinators, and other family medicine professionals IMPACT and ADVANCE the future of family medicine education

Register for the 2022 STFM Conference on Medical Student Education at stfm.org/mse

This conference is for anyone involved in the education of medical students: faculty, students, residents, coordinators, and community preceptors! Share this opportunity with friends, colleagues, and medical students.

\section{๑isTFM teachl A}

Do You Have Questions? Call STFM at (800) 274-7928 or email stfmoffice@stfm.org 